\title{
Sources of nitrous oxide emitted from European forest soils
}

\author{
P. Ambus ${ }^{1}$, S. Zechmeister-Boltenstern ${ }^{2}$, and K. Butterbach-Bahl ${ }^{3}$ \\ ${ }^{1}$ Risø National Laboratory, Biosystems Department (BIO-309), 4000 Roskilde, Denmark \\ ${ }^{2}$ Federal Research and Training Centre for Forests, Natural Hazards and Landscape (BFW), Vienna, Austria \\ ${ }^{3}$ Karlsruhe Research Centre, Institute for Meteorology and Climate Research, Atmospheric Environmental Research \\ (IMK-IFU), Garmisch-Partenkirchen, Germany
}

Received: 27 June 2005 - Published in Biogeosciences Discuss.: 9 September 2005

Revised: 16 November 2005 - Accepted: 23 December 2005 - Published: 20 March 2006

\begin{abstract}
Forest ecosystems may provide strong sources of nitrous oxide $\left(\mathrm{N}_{2} \mathrm{O}\right)$, which is important for atmospheric chemical and radiative properties. Nonetheless, our understanding of controls on forest $\mathrm{N}_{2} \mathrm{O}$ emissions is insufficient to narrow current flux estimates, which still are associated with great uncertainties. In this study, we have investigated the quantitative and qualitative relationships between $\mathrm{N}$-cycling and $\mathrm{N}_{2} \mathrm{O}$ production in European forests in order to evaluate the importance of nitrification and denitrification for $\mathrm{N}_{2} \mathrm{O}$ production. Soil samples were collected in 11 different sites characterized by variable climatic regimes and forest types. Soil N-cycling and associated production of $\mathrm{N}_{2} \mathrm{O}$ was assessed following application of ${ }^{15} \mathrm{~N}$-labeled nitrogen. The $\mathrm{N}_{2} \mathrm{O}$ emission varied significantly among the different forest soils, and was inversely correlated to the soil C:N ratio. The $\mathrm{N}_{2} \mathrm{O}$ emissions were significantly higher from the deciduous soils ( $13 \mathrm{ng} \mathrm{N}_{2} \mathrm{O}-\mathrm{N} \mathrm{cm}^{-3} \mathrm{~d}^{-1}$ ) than from the coniferous soils ( $\left.4 \mathrm{ng} \mathrm{N} \mathrm{N}_{2} \mathrm{O}-\mathrm{N} \mathrm{cm}^{-3} \mathrm{~d}^{-1}\right)$. Nitrate $\left(\mathrm{NO}_{3}^{-}\right)$was the dominant substrate for $\mathrm{N}_{2} \mathrm{O}$ with an average contribution of $62 \%$ and exceeding $50 \%$ at least once for all sites. The average contribution of ammonium $\left(\mathrm{NH}_{4}^{+}\right)$to $\mathrm{N}_{2} \mathrm{O}$ averaged $34 \%$. The $\mathrm{N}_{2} \mathrm{O}$ emissions were correlated with gross nitrification activities, and as for $\mathrm{N}_{2} \mathrm{O}$, gross nitrification was also higher in deciduous soils $\left(3.4 \mu \mathrm{g} \mathrm{N} \mathrm{cm}^{-3} \mathrm{~d}^{-1}\right)$ than in coniferous soils $\left(1.1 \mu \mathrm{g} \mathrm{N} \mathrm{cm}^{-3} \mathrm{~d}^{-1}\right)$. The ratio between $\mathrm{N}_{2} \mathrm{O}$ production and gross nitrification averaged $0.67 \%$ (deciduous) and $0.44 \%$ (coniferous). Our study suggests that changes in forest composition in response to land use activities and global change may have implications for regional budgets of greenhouse gases. From the study it also became clear that $\mathrm{N}_{2} \mathrm{O}$ emissions were driven by the nitrification activity, although the $\mathrm{N}_{2} \mathrm{O}$ was produced per se mainly from denitrification. Increased nitrification in response to accelerated $\mathrm{N}$ inputs predicted for forest ecosystems in Europe may thus lead to increased greenhouse gas emissions from forest ecosystems.
\end{abstract}

Correspondence to: P. Ambus

(per.ambus@risoe.dk)

\section{Introduction}

Nitrous oxide $\left(\mathrm{N}_{2} \mathrm{O}\right)$ is an important trace gas with implications for atmospheric chemistry and radiative properties (IPCC, 2001). Several independent studies have demonstrated that $\mathrm{N}_{2} \mathrm{O}$ is emitted in significant quantities from forest ecosystems (e.g. Ambus and Christensen, 1995; Bowden et al., 1990; Schmidt et al., 1989; Struwe and Kjøller, 1994; Papen and Butterbach-Bahl, 1999). In Europe, forest ecosystems cover about 1.9 Mill. $\mathrm{km}^{2}$ or ca. $28 \%$ of the total land area and may thus have significant importance for European scale $\mathrm{N}_{2} \mathrm{O}$ budgets. However, the importance of temperate forests for the atmospheric $\mathrm{N}_{2} \mathrm{O}$ budget still remains highly uncertain with a 20 -fold range in the emission estimates (IPCC, 2001). Such high uncertainty arise due to a combination of mere factors including lack of experimental data for upscaling, inevitable inaccuracy in flux measurements, and large spatial and temporal variability of fluxes (Kroeze et al., 2003). Moreover, insufficient process understanding for example on the importance of forest type and atmospheric $\mathrm{N}$-deposition is also an impediment to narrow flux estimates (Kroeze et al., 2003; Skiba et al., 1999).

Microbial $\mathrm{C}$ and $\mathrm{N}$ turnover processes, including mineralization, nitrification, denitrification and microbial immobilization are the main reason for $\mathrm{N}_{2} \mathrm{O}$ production and consumption in soils (Conrad, 2002). Therefore, a detailed knowledge of these processes is of fundamental importance to understand the microbially mediated biosphereatmosphere exchange of trace gases, and to build, parameterize and further improve process oriented models. Such models constitute crucial tools in the upscaling of plot-scale measurements in view of the large spatial and temporal variability of environmental conditions in forest ecosystems across Europe, and as tools to predict future $\mathrm{N}$ trace gas emissions from forest soils (Butterbach-Bahl et al., 2004).

The exchange of $\mathrm{N}_{2} \mathrm{O}$ between soils and the atmosphere depends specifically on the simultaneous, opposing processes of nitrification and denitrification (Wrage et al., 2001).

Published by Copernicus GmbH on behalf of the European Geosciences Union. 
Table 1. List of sampling sites with information on geographical location, species composition of tree stands, dominant undergrowth vegetation and forest age. The sites are grouped according to major forest type.

\begin{tabular}{|c|c|c|c|c|}
\hline Site (country) & Location & Tree species & $\begin{array}{l}\text { Dominant undergrowth vegeta- } \\
\text { tion }\end{array}$ & Age (yrs) \\
\hline \multicolumn{5}{|l|}{ Coniferous sites } \\
\hline Hyytiälä (SF) & $61.85^{\circ} \mathrm{N} 24.28^{\circ} \mathrm{E}$ & Scots pine (Pinus sylvestris) & Calluna vulgaris; Vaccinium sp. & 42 \\
\hline Glencorse (GB) & $55.85^{\circ} \mathrm{N} 2.17^{\circ} \mathrm{E}$ & Sitka spruce (Picea sitchensis) & None & 19 \\
\hline Speulderbos (NL) & $52.22^{\circ} \mathrm{N} 5.65^{\circ} \mathrm{E}$ & $\begin{array}{l}\text { Douglas fir } \quad \text { (Pseudotsuga } \\
\text { menziesii) }\end{array}$ & Scattered mosses & 41 \\
\hline Höglwald (D) & $48.50^{\circ} \mathrm{N} 11.17^{\circ} \mathrm{E}$ & Spruce (Picea abies) & Mosses & 110 \\
\hline Achenkirch (A) & $47.58^{\circ} \mathrm{N} 11.65^{\circ} \mathrm{E}$ & $\begin{array}{l}\text { Spruce-beech (Picea abies; } \\
\text { Fagus sylvatica) }\end{array}$ & $\begin{array}{l}\text { Carex alba; Sesleria albicans; } \\
\text { Melica nutans }\end{array}$ & 127 \\
\hline Nyirjes (HU) & $47.89^{\circ} \mathrm{N} 19.95^{\circ} \mathrm{E}$ & Spruce (Picea abies) & None & 40 \\
\hline San Rossore (I) & $43.73^{\circ} \mathrm{N} 10.28^{\circ} \mathrm{E}$ & Pine (Pinus pinaster) & $\begin{array}{l}\text { Pistacia lentiscus; Erica ar- } \\
\text { borea }\end{array}$ & 40 \\
\hline \multicolumn{5}{|l|}{ Deciduous sites } \\
\hline Sorø (DK) & $55.48^{\circ} \mathrm{N} 11.63^{\circ} \mathrm{E}$ & Beech (Fagus sylvatica) & Anemone nemorosa & $>80$ \\
\hline Schottenwald (A) & $48.23^{\circ} \mathrm{N} 15.25^{\circ} \mathrm{E}$ & Beech (Fagus sylvatica) & $\begin{array}{l}\text { Allium ursinum, Salvia gluti- } \\
\text { nosa }\end{array}$ & 142 \\
\hline Bosco negri (I) & $45.20^{\circ} \mathrm{N} 9.07^{\circ} \mathrm{E}$ & $\begin{array}{l}\text { Oak (Quercus robur); Poplar } \\
\text { (Populus spp); Ash (Fraxinus } \\
\text { spp) }\end{array}$ & $\begin{array}{l}\text { Convallaria majalis; Anemone } \\
\text { nemorosa }\end{array}$ & $>150$ \\
\hline Parco Ticino (I) & $45.20^{\circ} \mathrm{N} 9.07^{\circ} \mathrm{E}$ & $\begin{array}{l}\text { Poplar (Populus euroameri- } \\
\text { cana I-214) }\end{array}$ & None & 13 \\
\hline
\end{tabular}

Nitrification is an oxidative process that requires the availability of molecular oxygen and during which ammonium $\left(\mathrm{NH}_{4}^{+}\right)$is oxidised to nitrite $\left(\mathrm{NO}_{2}^{-}\right)$and nitrate $\left(\mathrm{NO}_{3}^{-}\right)$. In contrast, denitrification is a reductive process, which mainly occurs in oxygen depleted soil zones. Under anaerobic conditions, some microbes use $\mathrm{NO}_{3}^{-}$and $\mathrm{NO}_{2}^{-}$as alternative electron acceptors, thereby reducing $\mathrm{NO}_{3}^{-} / \mathrm{NO}_{2}^{-}$sequentially to $\mathrm{NO}, \mathrm{N}_{2} \mathrm{O}$ and finally to $\mathrm{N}_{2}$ (Conrad, 2002). Although nitrification and denitrification are characterized by different environmental controls and have optima under different environmental conditions, it is well known that both processes may occur simultaneously in the soil, thus giving rise to duplicate sources for $\mathrm{N}_{2} \mathrm{O}$ (Davidson et al., 2000).

The importance of other soil processes in the production of $\mathrm{N}_{2} \mathrm{O}$, including any role of dissimilatory nitrate reduction to ammonium, heterotrophic nitrification by fungi and anaerobic oxidation of $\mathrm{NH}_{4}^{+}$, remains poorly known, (e.g. Dalsgaard et al., 2003; Wolf and Brumme, 2002; Wrage et al., 2001).

In this experiment, we have investigated the quantitative and qualitative relationships between $\mathrm{N}$-cycling and $\mathrm{N}_{2} \mathrm{O}$ production in European forests in order to evaluate the importance of nitrification and denitrification for $\mathrm{N}_{2} \mathrm{O}$ production. Soil samples were collected in 11 different sites characterized by variable climatic regimes and forest types, and incubated in the laboratory under controlled environmental conditions. Soil N-cycling and associated production of $\mathrm{N}_{2} \mathrm{O}$ was assessed following application of ${ }^{15} \mathrm{~N}$-labeled nitrogen as tracer.

\section{Materials and methods}

\subsection{Study sites and sampling}

The study included 11 different forest sites situated across Europe from Finland in the north to Italy in the south, and from Scotland in the west to Hungary in the east. Main botanical characteristics are listed in Table 1 and soil characteristics are compiled in Table 2. Undisturbed soil samples were collected at each site in response to predefined conditions with respect to soil temperature to ensure identical preincubation conditions. Subsequent incubation took place in the laboratory under uniform temperature and moisture conditions. This procedure allowed identifying to which extent differences in chemical and biological conditions among the sites would lead to different $\mathrm{N}_{2} \mathrm{O}$ emission rates. At least two sampling occasions were considered for each site, i.e. at the onset of the growing season and at the end of the growing season, which subsequently will be mentioned as the spring time and autumn time samplings, respectively. The spring sampling took place when average soil temperature $(5 \mathrm{~cm}$ depth) exceeded $8^{\circ} \mathrm{C}$ and the autumn sampling took place 
Table 2. Soil characteristics of the study sites.

\begin{tabular}{llcccccc}
\hline Site & Soil texture & $\mathrm{pH}$ & $\% \mathrm{C}(\mathrm{dw})$ & $\% \mathrm{~N}(\mathrm{dw})$ & $\mathrm{C}: \mathrm{N}$ & $\mathrm{BD}^{\S}\left(\mathrm{g} \mathrm{cm}^{-3}\right)$ & WFPS! $^{\left(\% \mathrm{vol} \mathrm{vol}^{-1}\right)}$ \\
\hline Hyytiälä & Sandy loam & 3.7 & 4.3 & 0.27 & 16.3 & 0.71 & $48 \pm 7$ \\
Glencorse & Silty loam & 4.2 & 4.5 & 0.32 & 13.8 & 0.78 & $55 \pm 11$ \\
Speulderbos & Sand & 3.7 & 6.9 & 0.26 & 26.4 & 0.85 & $66 \pm 14$ \\
Höglwald & Loam & 3.7 & 12.5 & 0.56 & 22.7 & 0.33 & $62 \pm 13$ \\
Achenkirch & Loam & 7.0 & 14.1 & 0.80 & 17.8 & 0.43 & $68 \pm 14$ \\
Nyirjes & Sandy loam & 3.9 & 4.8 & 0.27 & 16.2 & 0.87 & $73 \pm 21$ \\
San Rossore & Sand & 5.8 & 2.7 & 0.08 & 35.9 & 0.86 & $38 \pm 8$ \\
Sorø & Loamy sand & 4.5 & 2.6 & 0.15 & 17.7 & 0.85 & $58 \pm 8$ \\
Schottenwald & Silty loam & 4.2 & 3.6 & 0.25 & 15.0 & 0.88 & $58 \pm 12$ \\
Bosco negri & Loamy sand & 4.2 & 5.6 & 0.42 & 12.5 & 0.58 & $50 \pm 12$ \\
Parco Ticino & Sandy loam & 5.9 & 1.2 & 0.10 & 12.0 & 1.15 & $70 \pm 28$ \\
\hline
\end{tabular}

$\S$ Bulk density of incubated soil cores.

! Water filled pore space $( \pm S E)$ measured after incubation.

when soil temperature had decreased to below $5^{\circ} \mathrm{C}$. In the Hyytiälä and Sorø sites, two additional samplings were conducted in early summer (June) and late summer (September), respectively. In the San Rossore site a spring time sample was not achieved until June.

At each sampling, 16 intact soil cores, $5 \mathrm{~cm}$ diam., were collected from the top $0-10 \mathrm{~cm}$ soil after removal of the litter layer by pushing down $10 \mathrm{~cm}$ long PVC-cylinders sharpened at the bottom end. The cores were gently excavated, sealed firmly by wrapping with Parafilm ${ }^{\circledR}$ and then shipped in a cool box to the laboratory by overnight carrier.

\subsection{Incubation}

Upon arrival to the laboratory, the samples were stored in a cold room $\left(5^{\circ} \mathrm{C}\right)$ until incubation was initiated, within one week. Incubation included a two-step procedure. Firstly, the soil water content was adjusted to a $\mathrm{pF}$ value of 2.36 . The Parafilm ${ }^{\circledR}$ was removed and the cores wrapped at the bottom by a cotton cloth and then gently wetted with $40 \mathrm{ml}$ of deionised water. Subsequently a $230 \mathrm{~cm}$ water suction was applied to the bottom of the cores achieved by placing them in an elevated sandbox for $60 \mathrm{~h}$ at $5^{\circ} \mathrm{C}$. After equilibration of the soil water content, the cores were re-sealed at the bottom. Then, three quadruplicate sets of cores were treated with different combinations of nitrogen-15 enriched substrates prior to incubation for $\mathrm{N}_{2} \mathrm{O}$ flux measurements and gross $\mathrm{N}$-cycling assay. In treatment $A{ }^{15} \mathrm{~N}$-enriched $\mathrm{NH}_{4}^{+}$ was added as a ${ }^{15}\left(\mathrm{NH}_{4}\right)_{2} \mathrm{SO}_{4}$ solution with 2 atom\% excess (APE) ${ }^{15} \mathrm{~N}$; in treatment $N^{15} \mathrm{~N}$-enriched $\mathrm{NO}_{3}^{-}$was added as a $\mathrm{K}^{15} \mathrm{NO}_{3}$ solution (2 APE). A third set of cores received both ${ }^{15} \mathrm{NH}_{4}^{+}$and ${ }^{15} \mathrm{NO}_{3}^{-}$and was subject to immediate extraction for dissolved inorganic $\mathrm{N}$ to assess start values. A fourth treatment constituted a zero $\mathrm{N}$ control by adding deionised water. The solutions were applied in six 1-ml doses provid- ing $300 \mu \mathrm{g} \mathrm{N}$ core $^{-1}$ and a homogeneous distribution of the applied $\mathrm{N}$ was ensured by injecting slowly in synchrony with the vertical $0-8 \mathrm{~cm}$ travel of a side hole needle facilitated by the use of a precision liquid processor (Hamilton Microlab 500). The cores were then incubated in individuality at $15^{\circ} \mathrm{C}$ for $48 \mathrm{~h}$ in a 2-1 gas tight Kilner jar fitted with a rubber septum in the lid for headspace gas sampling by syringe and needle. A small beaker with water in the jars served to prevent evaporation losses from the cores. Two gas samples were removed from the headspace at 0,24 and $48 \mathrm{~h}$, respectively, for subsequent analysis of headspace $\mathrm{N}_{2} \mathrm{O}$ concentrations and ${ }^{15} \mathrm{~N}$ enrichments of $\mathrm{N}_{2} \mathrm{O}$. A 5-ml sample was transferred to a pre-evacuated 3-ml Venoject ${ }^{\circledR}$ blood-collecting tube for the $\mathrm{N}_{2} \mathrm{O}$ concentration measurements, and a $120-\mathrm{ml}$ sample was transferred to a pre-evacuated crimp-sealed 100$\mathrm{ml}$ serum bottle for determination of ${ }^{15} \mathrm{~N}$ content in the $\mathrm{N}_{2} \mathrm{O}$. Prior to each sampling, the Kilner jars were pressurized with an equal amount of $\mathrm{N}_{2}$ to maintain atmospheric headspace pressure.

\subsection{Analysis}

The soil cores were analyzed for inorganic $\mathrm{N}$ contents and ${ }^{15} \mathrm{~N}$ enrichments two hours and $48 \mathrm{~h}$ after the label was applied. The soil was removed from the PVC cylinder, mixed thoroughly by hand and sieved to pass a $2 \mathrm{~mm}$ mesh. Subsamples of $20 \mathrm{~g}$ were suspended in $100 \mathrm{ml}$ of $1 \underline{M ~ K C l}$ and shaken for $1 \mathrm{~h}$ prior to filtration and analysis of inorganic $\mathrm{N}$ and ${ }^{15} \mathrm{~N}$.

Gross $\mathrm{N}$ turnover rates were calculated based on the ${ }^{15} \mathrm{~N}$ isotope pool dilution principle using the analytical equations of Kirkham and Bartholomew (1954). Gross rates of N mineralization were obtained from the isotopic dilution of the $\mathrm{NH}_{4}^{+}$pool in treatment $A$. Gross rates of nitrification were obtained from the isotopic dilution of the $\mathrm{NO}_{3}^{-}$pool in treatment $N$. Net nitrification was calculated from the change 


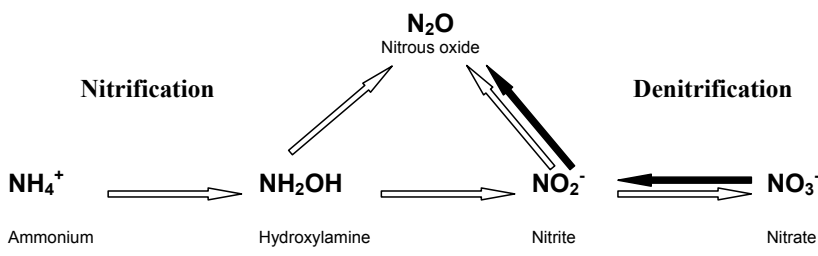

Fig. 1. Conceptual model indicating the major pathways for $\mathrm{N}_{2} \mathrm{O}$ formation regarded in this study. Nitrification is indicated with open arrows and denitrification is indicated with bold arrows. Adapted from Wrage et al. (2001).

in soil $\mathrm{NO}_{3}^{-}$concentrations in treatment $N$ over the two-day incubation.

The contribution of $\mathrm{NH}_{4}^{+}$to $\mathrm{N}_{2} \mathrm{O}$ production $(\mathrm{Fa})$ was achieved in treatment $A$ by the use of the linear mixing model $\mathrm{Fa}=(\mathrm{NOe}-\mathrm{NIe}) /(\mathrm{AMe}-\mathrm{NIe})$, where $\mathrm{NOe}, \mathrm{NIe}$ and AMe are the atom $\%{ }^{15} \mathrm{~N}$ enrichments of $\mathrm{N}_{2} \mathrm{O}, \mathrm{NO}_{3}^{-}$and $\mathrm{NH}_{4}^{+}$, respectively. NOe was calculated from the paired measurements of $\mathrm{N}_{2} \mathrm{O}$ concentration and ${ }^{15} \mathrm{~N}$ enrichments in the incubation jar. NIe and AMe were calculated as the average between the $\mathrm{NO}_{3}^{-}$and $\mathrm{NH}_{4}^{+}$enrichments, respectively, observed at the onset and at the end of the incubations. The Fa-value was calculated under the assumptions that labeled $\mathrm{NH}_{4}^{+}$and labeled $\mathrm{NO}_{3}^{-}$were the only sources for $\mathrm{N}_{2} \mathrm{O}$ as illustrated in the simple, conceptual model pictured in Fig. 1. The contribution of $\mathrm{NO}_{3}^{-}$to the $\mathrm{N}_{2} \mathrm{O}$ production ( $\mathrm{Fn}$ ) was evaluated from the results of experiment $N$ by the approach $\mathrm{Fn}=\mathrm{NOe} / \mathrm{NIe}$.

Concentrations of $\mathrm{N}_{2} \mathrm{O}$ were measured by gas chromatography (Shimadzu GC 14B, Kyoto, Japan) with electron capture detection. The ${ }^{15} \mathrm{~N}$ content of $\mathrm{N}_{2} \mathrm{O}$ was analysed using a Finnigan MAT PreCon unit (ThermoFinnigan, Bremen, Germany) interfaced with a GC coupled in continuous flowmode to a Finnigan MAT Delta PLUS isotope ratio mass spectrometer (IRMS). Briefly, using a double hole needle and He carrier the sample in the 100-ml serum bottle was purged through a chemical trap of $\mathrm{Mg}\left(\mathrm{ClO}_{4}\right)_{2}$ and Ascarite $(\mathrm{KOH})$ for removal of water and $\mathrm{CO}_{2}$, respectively, and the sample $\mathrm{N}_{2} \mathrm{O}$ was then concentrated cryogenically (liq. $\mathrm{N}_{2}$ ) before injection into the GC.

Soil extracts were analysed for concentrations of $\mathrm{NH}_{4}^{+}$ and $\mathrm{NO}_{3}^{-}$on a Bran+Luebbe AutoAnalyzer 3 system (Bran+Luebbe, Norderstedt, Germany). To determine the ${ }^{15} \mathrm{~N}$ enrichments of $\mathrm{NH}_{4}^{+}$and $\mathrm{NO}_{3}^{-}$, the content of each component in an 80-ml portion of the $\mathrm{KCl}$ extract was concentrated on acidified filter paper prior to analysis (Sørensen and Jensen, 1991).

Soil total $\mathrm{N}$ and ${ }^{15} \mathrm{~N}$ was determined in finely ground 40 mg portions of air-dried soil samples. Dried filter papers and soil samples were wrapped in tin cups followed by analysis on a CE 1110 elemental analyser (ThermoFinnigan, Milan, Italy) coupled in continuous flow mode to the IRMS.

Soil moisture was determined gravimetrically $\left(105^{\circ} \mathrm{C}\right.$,
$24 \mathrm{~h})$ and $\mathrm{pH}$ was measured in water suspension (1:2.5 w:vol) of air-dried soil samples.

The sites differed considerably in bulk densities (Table 2) and to facilitate comparisons between sites data are given on basis of soil volume. Statistical evaluation of the data was undertaken using S-PLUS ${ }^{\circledR}$ (Insightful Corporation, Seattle, USA). Two-sample population means were compared using t-tests. Main effects of site and time were evaluated by analysis of variance (ANOVA). Where the main effects were significant, multiple-means comparisons were done by the Tukey critical point calculation to determine differences in response factors. Single linear regression and stepwise multiple linear regression analysis was used to describe the effect of single or multiple variables upon response variables. Data were assumed normally distributed except for $\mathrm{N}_{2} \mathrm{O}$ fluxes, which were log-transformed before evaluation. All tests were performed at the $5 \%$ probability level.

\section{Results}

\subsection{Site characteristics}

The 11 sites included in this study represented seven different major tree species, comprising both deciduous and coniferous forest types (Table 1), which were distributed on five different soil textures ranging from sand to loam (Table 2). Except for the Achenkirch site, which was located on limestone (Schindlbacher et al., 2004), all sites were characterized by acidic pH-values (Table 2). The Höglwald and Achenkirch spruce soils revealed notably high organic $\mathrm{C}$ contents of $12.5 \%$ and $14.1 \%$, respectively. For the remaining soils organic $\mathrm{C}$ ranged between $1.2 \%$ and $6.9 \%$ (Table 2). The soil moisture adjustments prior to the incubations combined with the subsequent substrate additions resulted in soil water filled pore spaces (WFPS) ranging from $38 \%$ in the sandy San Rossore soil to $73 \%$ in the sandy loam soil of Nyirjes (Table 2).

Soil inorganic nitrogen contents varied between sampling times in three of the sites (Table 3). Between the sites, $\mathrm{NH}_{4}^{+}$was uniform in the spring, whereas in the autumn the Hyytiälä site contained most $\mathrm{NH}_{4}^{+}$. Soil $\mathrm{NO}_{3}^{-}$in the spring reached peak values in Glencorse whereas in the autumn soil $\mathrm{NO}_{3}^{-}$in Bosco negri exceeded most other sites $(\mathrm{P}<0.001$ for all effects). The early summer and late summer samplings in Hyytiälä and Sorø showed that the two sites differed in $\mathrm{NH}_{4}^{+}$ in the late summer, but otherwise remained similar.

\subsection{Emissions of $\mathrm{N}_{2} \mathrm{O}$ from soil columns}

During the $48 \mathrm{~h}$ incubation time, the majority of the forest soil columns emitted $\mathrm{N}_{2} \mathrm{O}$ at median values ranging from $<0.5 \mathrm{ng} \mathrm{N}_{2} \mathrm{O}-\mathrm{N} \mathrm{cm} \mathrm{cm}^{-3} \mathrm{~d}^{-1}$ in the Hyytiälä soils to about $15 \mathrm{ng} \mathrm{N}_{2} \mathrm{O}-\mathrm{N} \mathrm{cm}^{-3} \mathrm{~d}^{-1}$ in soil from the Schottenwald beech forest (Fig. 2). At three occasions a slight decrease in $\mathrm{N}_{2} \mathrm{O}$ headspace concentrations was observed suggesting that 

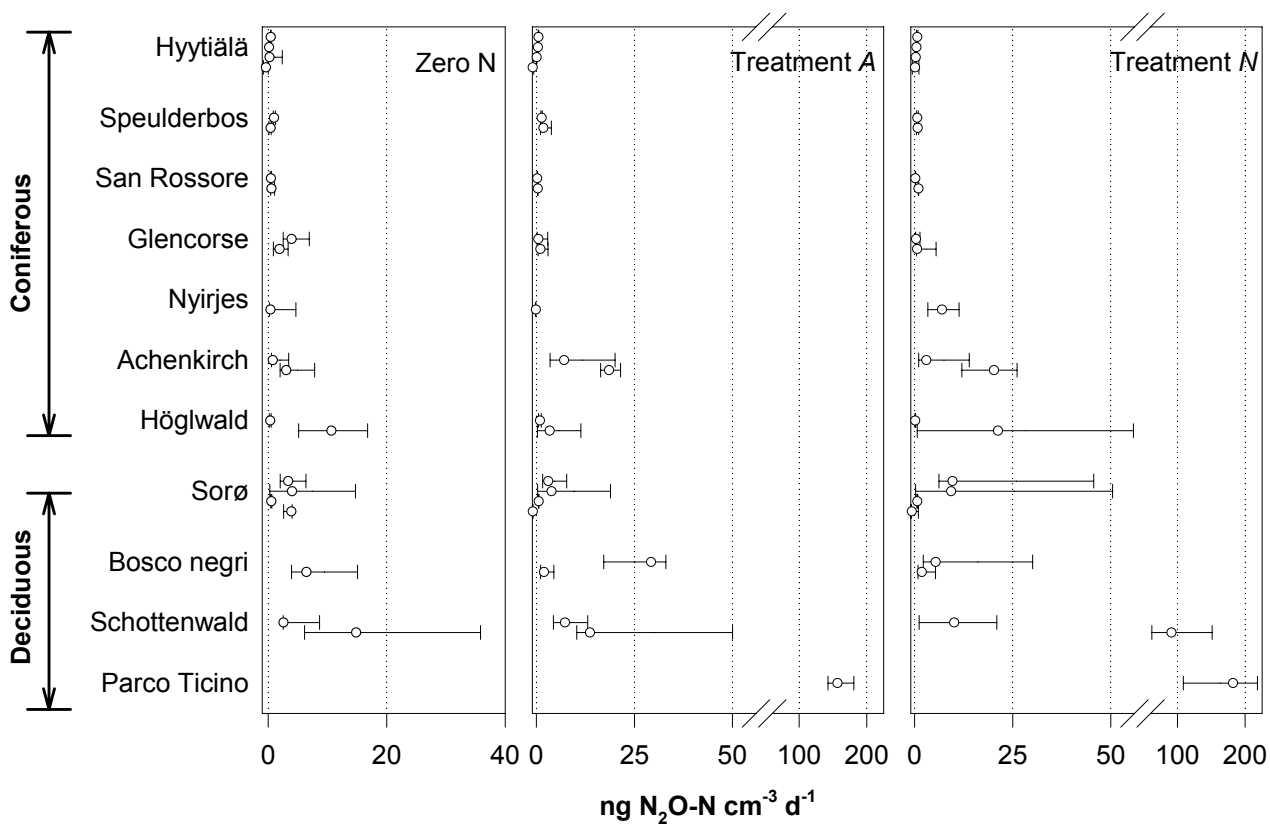

Fig. 2. Emissions of $\mathrm{N}_{2} \mathrm{O}$ from soil cores incubated after soil moisture adjustment only (zero $\mathrm{N}$ ), after ${ }^{15} \mathrm{NH}_{4}^{+}$additions (treatment $A$ ) and after ${ }^{15} \mathrm{NO}_{3}^{-}$additions (treatment $N$ ), respectively. Data points indicate the median value for each sampling occasion and horizontal bars indicate the 25 percentile and 75 percentile boundaries. For each forest type the sites are grouped along the vertical axis according to $\mathrm{N}_{2} \mathrm{O}$ emission magnitude. Sampling times for the sites were Hyytiälä (May, June, August, November); Speulderbos (April, December); San Rossore (June, Janauary); Glencorse (April, December); Nyirjes (December); Achenkirch (April, November); Höglwald (April, December); Sorø (May, June, September, November); Bosco negri (May, January); Schottenwald (April, November); Parco Ticino (May).

$\mathrm{N}_{2} \mathrm{O}$ uptake occurred, but always at low rates $<1 \mathrm{ng} \mathrm{N}_{2} \mathrm{O}-\mathrm{N}$ $\mathrm{cm}^{-3} \mathrm{~d}^{-1}$ (Hyytiälä autumn with $\mathrm{NH}_{4}^{+}$, Nyirjes with $\mathrm{NH}_{4}^{+}$, and Sorø autumn with $\mathrm{NH}_{4}^{+}$, respectively). Sampling time had no influence on the $\mathrm{N}_{2} \mathrm{O}$ activity except for the Höglwald site, where $\mathrm{N}_{2} \mathrm{O}$ emission was greater in the autumn than in the spring $(\mathrm{P}<0.05)$. Addition of the $\mathrm{NH}_{4}^{+}$and $\mathrm{NO}_{3}^{-}$substrates roughly doubled the $\mathrm{N}_{2} \mathrm{O}$ activity, independent of substrate form, when all sites and sampling times are combined (Fig. 2). However, due to the prevalent scatter in data the $\mathrm{N}$ effect was only significant in the Nyirjes soil in the autumn where activity peaked at $7 \mathrm{ng} \mathrm{N} \mathrm{N}_{2} \mathrm{O}-\mathrm{N} \mathrm{cm}^{-3} \mathrm{~d}^{-1}$ after $\mathrm{NO}_{3}^{-}$ additions and in the Höglwald soil in the spring where activity peaked at $0.9 \mathrm{ng} \mathrm{N} 2 \mathrm{O}-\mathrm{N} \mathrm{cm}^{-3} \mathrm{~d}^{-1}$ upon $\mathrm{NH}_{4}^{+}$-addition.

The $\mathrm{N}_{2} \mathrm{O}$ emission varied significantly among the different forest soils both under zero $\mathrm{N}$ conditions as well as for the nitrogen amended soil columns $(\mathrm{P}<0.001)$. This site related effect on $\mathrm{N}_{2} \mathrm{O}$ emissions remained significant also when the asymptotic high values for the Parco Ticino (Fig. 2) was removed in the ANOVA. The average $\mathrm{N}_{2} \mathrm{O}$ emission in the zero $\mathrm{N}$ samples was inversely correlated $(\mathrm{P}<0.05)$ to the soil $\mathrm{C}: \mathrm{N}$ ratio (Table 1), but did not correlate with any other of the soil variables listed in Tables 2 and 3. The $\mathrm{N}_{2} \mathrm{O}$ emissions from the zero $\mathrm{N}$ samples were significantly $(\mathrm{P}<0.01)$ higher from the deciduous soils ( $13 \mathrm{ng} \mathrm{N}_{2} \mathrm{O}-\mathrm{N} \mathrm{cm}^{-3} \mathrm{~d}^{-1}$ ) than from the coniferous soils $\left(4 \mathrm{ng} \mathrm{N} \mathrm{N}_{2} \mathrm{O}-\mathrm{N} \mathrm{cm}^{-3} \mathrm{~d}^{-1}\right)$. A similar effect of forest type was also significant $(\mathrm{P}<0.05)$ with the $\mathrm{NO}_{3}^{-}$ treated soil columns, and a trend $(\mathrm{P}<0.06)$ was evident for the $\mathrm{NH}_{4}^{+}$treated soils, also when the asymptotic values for the Parco Ticino poplar site were excluded from the analysis.

\subsection{Sources for $\mathrm{N}_{2} \mathrm{O}$}

The data in Fig. 3 shows the average ${ }^{15} \mathrm{~N}$ enrichments of the inorganic $\mathrm{N}$ pools during the course of the incubation, combined with the ${ }^{15} \mathrm{~N}$ enrichment of the cumulated $\mathrm{N}_{2} \mathrm{O}$. Two days after the ${ }^{15} \mathrm{NH}_{4}^{+}$-labelling (treatment $A$ ) an increase in ${ }^{15} \mathrm{NO}_{3}^{-}$could be observed for most of the soils indicating that nitrification occurred (Fig. 3). The ${ }^{15} \mathrm{~N}$ enrichments of the $\mathrm{N}_{2} \mathrm{O}$ emitted from ${ }^{15} \mathrm{NH}_{4}^{+}$-labeled soil columns varied considerably among the different sites. For some sites, e.g. Hyytiälä, Speulderbos (spring), and San Rossore the emitted $\mathrm{N}_{2} \mathrm{O}$ contained almost no excess ${ }^{15} \mathrm{~N}$ despite significant enrichments of both the $\mathrm{NH}_{4}^{+}$and $\mathrm{NO}_{3}^{-}$pools. In the remaining sites, the $\mathrm{N}_{2} \mathrm{O}$ enrichments were intermediate to the enrichments of the $\mathrm{NH}_{4}^{+}$and $\mathrm{NO}_{3}^{-}$pools, apart for three observations (Hyytiälä late summer, Achenkirch autumn and Höglwald autumn) where the $\mathrm{N}_{2} \mathrm{O}{ }^{15} \mathrm{~N}$ enrichments exceeded the enrichments of both inorganic $\mathrm{N}$ pools (Fig. 3). With the ${ }^{15} \mathrm{NO}_{3}^{-}$-labelled soil (treatment $N$ ) no increase in ${ }^{15} \mathrm{NH}_{4}^{+}$was observed. The ${ }^{15} \mathrm{~N}$ isotopic signature of emitted $\mathrm{N}_{2} \mathrm{O}$ was less than that of the $\mathrm{NO}_{3}^{-}$-pool to varying degrees indicating variable source strengths of $\mathrm{NO}_{3}^{-}$for $\mathrm{N}_{2} \mathrm{O}$ 
Table 3. Soil inorganic N contents at each sampling occasion.

\begin{tabular}{|c|c|c|c|}
\hline \multirow[t]{2}{*}{ Location } & \multirow[t]{2}{*}{ Sampling time $(\mathrm{mo})$} & \multicolumn{2}{|c|}{ Inorganic nitrogen content $\left(\mu \mathrm{g} \mathrm{N} \mathrm{cm}^{-3}\right)$} \\
\hline & & $\mathrm{NH}_{4}^{+}$ & $\mathrm{NO}_{3}^{-}$ \\
\hline \multirow[t]{4}{*}{ Hyytiälä } & Spring (May) & $7.7^{\S}$ & $0.3^{\S}$ \\
\hline & Early summer (June) & 0 & 0.7 \\
\hline & Late summer (Aug) & 6.4 & 2.0 \\
\hline & Autumn (Nov) & 30.3 & 0.2 \\
\hline \multirow[t]{2}{*}{ Glencorse } & Spring (April) & 7.1 & 11.1 \\
\hline & Autumn (Dec) & 1.8 & 5.8 \\
\hline \multirow[t]{2}{*}{ Speulderbos } & Spring (April) & 3.7 & $0.5^{\S}$ \\
\hline & Autumn (Dec) & 6.1 & 5.4 \\
\hline \multirow[t]{2}{*}{ Höglwald } & Spring (April) & 0.6 & 4.2 \\
\hline & Autumn (Dec) & 1.1 & 2.2 \\
\hline \multirow[t]{2}{*}{ Achenkirch } & Spring (April) & 2.6 & 7.1 \\
\hline & Autumn (Nov) & 2.9 & 1.6 \\
\hline \multirow[t]{2}{*}{ Nyirjes } & Spring (n.a.) & n.a. & n.a. \\
\hline & Autumn (Dec) & 1.5 & 0.5 \\
\hline \multirow[t]{2}{*}{ San Rossore } & Spring/Summer (June) & 0 & 0.3 \\
\hline & Autumn (Jan) & 1.3 & 0.4 \\
\hline \multirow[t]{4}{*}{ Sor $\varnothing$} & Spring (May) & $0^{\S}$ & $1.4^{\S}$ \\
\hline & Early summer (June) & 8.3 & 0.2 \\
\hline & Late summer (Sep) & 0.6 & 0.8 \\
\hline & Autumn (Nov) & 0 & 1.2 \\
\hline \multirow[t]{2}{*}{ Schottenwald } & Spring (April) & 3.5 & 6.8 \\
\hline & Autumn (Nov) & 0.4 & 5.5 \\
\hline \multirow[t]{2}{*}{ Bosco negri } & Spring (May) & 2.8 & 11.3 \\
\hline & Autumn (Jan) & 5.3 & 13.3 \\
\hline \multirow[t]{2}{*}{ Parco Ticino } & Spring (May) & 19.7 & 11.0 \\
\hline & Autumn (n.a.) & n.a. & n.a. \\
\hline
\end{tabular}

$\S$ : Indicates significant differences between sampling times. n.a.: Data not available.

production between the sites. Unexpected high ${ }^{15} \mathrm{~N}$ enrichments of $\mathrm{N}_{2} \mathrm{O}$ were observed at two occasions, i.e. Nyirjes autumn and Achenkirch autumn (Fig. 3).

The contribution of $\mathrm{NH}_{4}^{+}$to $\mathrm{N}_{2} \mathrm{O}$ in experiment $A$ and the contribution of $\mathrm{NO}_{3}^{-}$to $\mathrm{N}_{2} \mathrm{O}$ in experiment $N$, calculated from the ${ }^{15} \mathrm{~N}$ values in Fig. 3, suggests that $\mathrm{NO}_{3}^{-}$was the dominant source for $\mathrm{N}_{2} \mathrm{O}$ on most occasions across sampling time and location (Table 4). The contribution of $\mathrm{NH}_{4}^{+}$to $\mathrm{N}_{2} \mathrm{O}$ averaged 34\%. Data for the Achenkirch site showed that the contribution from $\mathrm{NH}_{4}^{+}$consistently exceeded $50 \%$, which was significantly $(\mathrm{P}<0.05)$ higher than for the other sites except Hyytiälä, Bosco negri and Parco Ticino. In contrast, we found that the contribution of $\mathrm{NO}_{3}^{-}$to $\mathrm{N}_{2} \mathrm{O}$ averaged $62 \%$ and exceeded $50 \%$ in at least one observation in each site, but independent of sampling time. The Höglwald site revealed a significantly higher $\mathrm{NO}_{3}^{-}$source strength $(\mathrm{P}<0.01)$ than Hyytiälä, San Rossore, Achenkirch and Sorø (Table 3). The source strengths of $\mathrm{NH}_{4}^{+}$and $\mathrm{NO}_{3}^{-}$to $\mathrm{N}_{2} \mathrm{O}$ were not influenced by major forest type, i.e. deciduous versus coniferous.

\subsection{Gross $\mathrm{N}$ cycling rates}

Gross $\mathrm{N}$ mineralization varied significantly between the sampling sites for both springtime samples and autumn-time samples, and four sites, i.e. Hyytiälä, Glencorse, Achenkirch, and Sorø, also varied between sampling times (Fig. 4). The lowest gross mineralization, $0.6 \mu \mathrm{g} \mathrm{N} \mathrm{cm}^{-3} \mathrm{~d}^{-1}$, was observed in a coniferous site (Hyytiälä in autumn) and the highest, $13.3 \mu \mathrm{g} \mathrm{N} \mathrm{cm}^{-3} \mathrm{~d}^{-1}$, in a deciduous site (Bosco negri in spring). The average coniferous activity of $3.3 \mu \mathrm{g} \mathrm{N}$ $\mathrm{cm}^{-3} \mathrm{~d}^{-1}$, however, did not differ from the average deciduous activity of $4.2 \mu \mathrm{g} \mathrm{N} \mathrm{cm}^{-3} \mathrm{~d}^{-1}$. A step-wise multiple regression analysis with mean gross mineralization rates as response variable and soil physical and chemical characteristics (Tables 2 and 3) as main effects indicated a negative correlation with soil total $\mathrm{C}(\mathrm{P}<0.05)$ and a positive correlation with soil total $\mathrm{N}(\mathrm{P}<0.05)$.

Gross nitrification rates ranged from $<0.1 \mu \mathrm{g} \mathrm{N} \mathrm{cm}^{-3} \mathrm{~d}^{-1}$ to $5.7 \mu \mathrm{g} \mathrm{N} \mathrm{cm}^{-3} \mathrm{~d}^{-1}$, and fluctuated significantly among sites in the spring, but not autumn (Fig. 4). Sampling time fluctuations were evident only at two sites, i.e. Hyytiälä and 


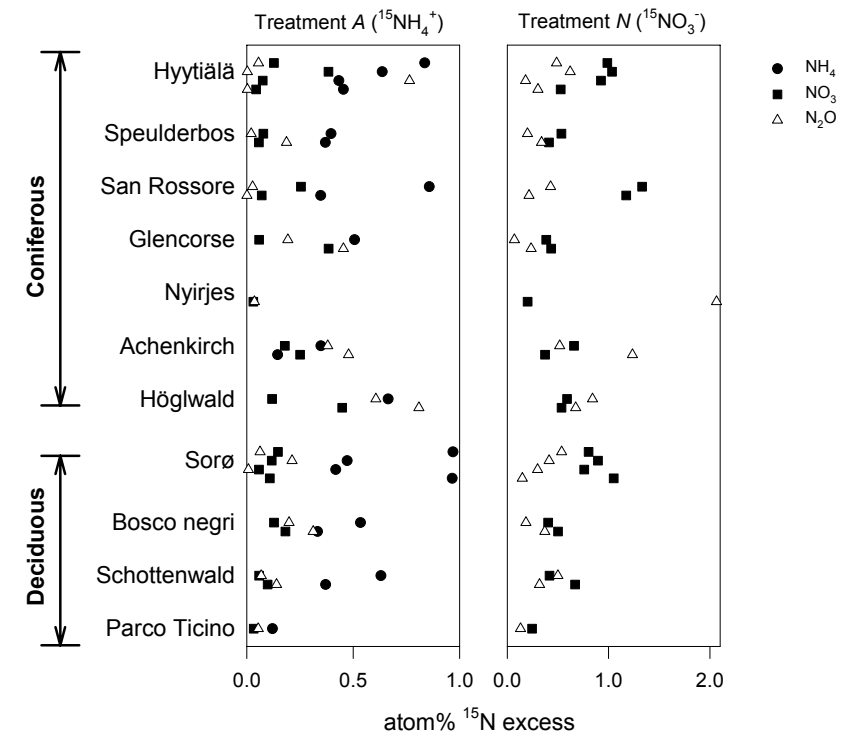

Fig. 3. Nitrogen-15 enrichments of soil $\mathrm{NH}_{4}^{+}$, soil $\mathrm{NO}_{3}^{-}$and emitted $\mathrm{N}_{2} \mathrm{O}$, respectively, after ${ }^{15} \mathrm{NH}_{4}^{+}$additions (treatment $A$ ) and ${ }^{15} \mathrm{NO}_{3}^{-}$additions (treatment $N$ ). Data points indicate the atom\% ${ }^{15} \mathrm{~N}$ excess for each component. Data for $\mathrm{NH}_{4}^{+}$and $\mathrm{NO}_{3}^{-}$are averages between the initial and final samplings during the incubation. The sites are grouped along the vertical axis according to Fig. 2.

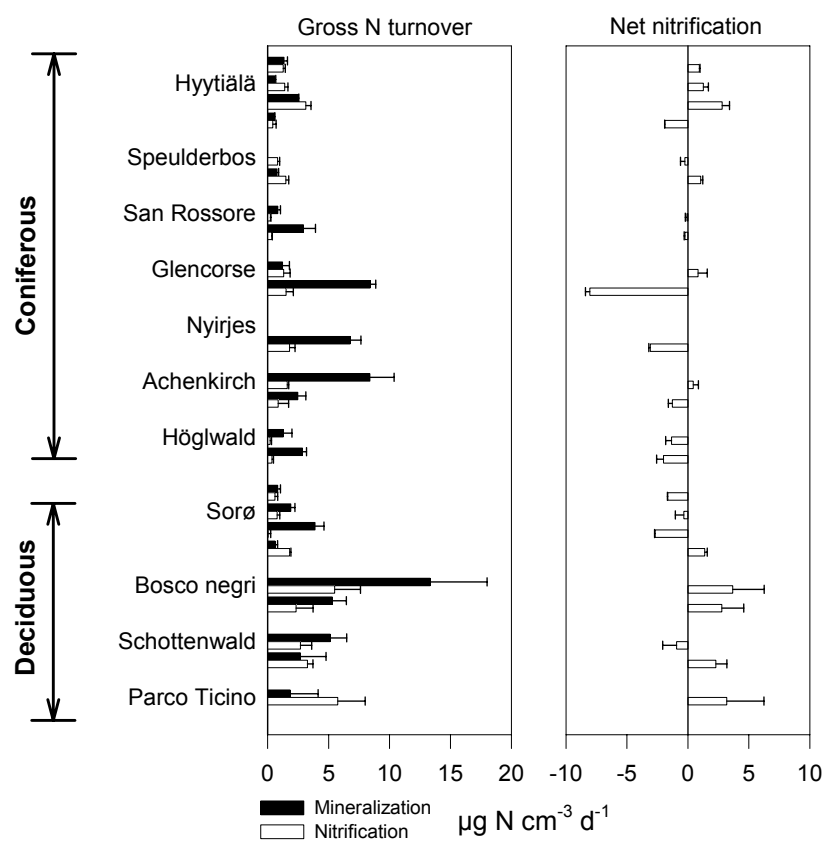

Fig. 4. Left hand plot shows rates of gross $\mathrm{N}$ mineralization and gross nitrification obtained from treatment $A$ and treatment $N$, respectively. Right hand plot shows net nitrification rates obtained from treatment $N$. The bars indicate mean rates $(\mathrm{n}=4+1 \mathrm{SE})$ from each sampling occasion. The vertical grouping is according to Fig. 2.
Table 4. The contribution of $\mathrm{NH}_{4}^{+}$and $\mathrm{NO}_{3}^{-}$to $\mathrm{N}_{2} \mathrm{O}$ formation. The numbers are percent of produced $\mathrm{N}_{2} \mathrm{O}$ derived from ${ }^{15} \mathrm{~N}$-labeled $\mathrm{NH}_{4}^{+}$(treatment $A$ ) and $\mathrm{NO}_{3}^{-}$(treatment $N$ ), respectively.

\begin{tabular}{|c|c|c|c|}
\hline \multirow[t]{2}{*}{ Location } & \multirow[t]{2}{*}{ Sampling time $(\mathrm{mo})$} & \multicolumn{2}{|c|}{$\%$ contribution to $\mathrm{N}_{2} \mathrm{O}^{\S}$} \\
\hline & & From ${ }^{15} \mathrm{NH}_{4}^{+}$ & From ${ }^{15} \mathrm{NO}_{3}^{-}$ \\
\hline \multirow[t]{4}{*}{ Hyytiälä } & Spring (May) & $0 \pm 9$ & $50 \pm 4$ \\
\hline & Early summer (June) & $0 \pm 9$ & $60 \pm 29$ \\
\hline & Late summer (Aug) & $\sim 100 \pm 24$ & $19 \pm 5$ \\
\hline & Autumn (Nov) & $0 \pm 1$ & $88 \pm 14$ \\
\hline \multirow[t]{2}{*}{ Glencorse } & Spring (April) & $32 \pm 11$ & $19 \pm 4$ \\
\hline & Autumn (Dec) & n.a. & $53 \pm 9$ \\
\hline \multirow[t]{2}{*}{ Speulderbos } & Spring (April) & $0 \pm 5$ & $37 \pm 6$ \\
\hline & Autumn (Dec) & $40 \pm 8$ & $84 \pm 21$ \\
\hline \multirow[t]{2}{*}{ Höglwald } & Spring (April) & $92 \pm 11$ & $100 \pm 16$ \\
\hline & Autumn (Dec) & n.a. & $100 \pm 20$ \\
\hline \multirow[t]{2}{*}{ Achenkirch } & Spring (April) & $100 \pm 15$ & $80 \pm 11$ \\
\hline & Autumn (Nov) & $\sim 100 \pm 12$ & $\sim 100 \pm 21$ \\
\hline \multirow[t]{2}{*}{ Nyirjes } & Spring (n.a.) & n.a. & n.a. \\
\hline & Autumn (Dec) & n.a. & $\sim 100 \pm 8$ \\
\hline \multirow[t]{2}{*}{ San Rossore } & Spring/Summer (June) & $0 \pm 8$ & $33 \pm 15$ \\
\hline & Autumn (Jan) & $0 \pm 2$ & $19 \pm 8$ \\
\hline \multirow[t]{4}{*}{ Sorø } & Spring (May) & $0 \pm 8$ & $62 \pm 34$ \\
\hline & Early summer (June) & $27 \pm 23$ & $47 \pm 7$ \\
\hline & Late summer (Sep) & $0 \pm 1$ & $40 \pm 6$ \\
\hline & Autumn (Nov) & n.a. & $18 \pm 19$ \\
\hline \multirow[t]{2}{*}{ Schottenwald } & Spring (April) & $2 \pm 3$ & $100 \pm 20$ \\
\hline & Autumn (Nov) & $12 \pm 7$ & $47 \pm 16$ \\
\hline \multirow[t]{2}{*}{ Bosco negri } & Spring (May) & $21 \pm 11$ & $45 \pm 3$ \\
\hline & Autumn (Jan) & $53 \pm 17$ & $69 \pm 23$ \\
\hline \multirow[t]{2}{*}{ Parco Ticino } & Spring (May) & $22 \pm 2$ & $53 \pm 3$ \\
\hline & Autumn (n.a.) & n.a. & n.a. \\
\hline
\end{tabular}

$\S$ : The contribution of ${ }^{15} \mathrm{NH}_{4}^{+}$and ${ }^{15} \mathrm{NO}_{3}^{-}$, respectively to ${ }^{15} \mathrm{~N}_{2} \mathrm{O}$ production in experiment $A$ and experiment $N$. Mean of $\mathrm{n}=2-4$ samples \pm SE.

n.a.: data not available.

Sorø, where sampling took place four times during the season. The average coniferous gross nitrification of $1.1 \mu \mathrm{g} \mathrm{N}$ $\mathrm{cm}^{-3} \mathrm{~d}^{-1}$ was significantly $(\mathrm{P}<0.01)$ lower than the deciduous activity of $3.4 \mu \mathrm{g} \mathrm{N} \mathrm{cm}^{-3} \mathrm{~d}^{-1}$. Across all sites, the average gross nitrification was inversely correlated to the soil $\mathrm{C}: \mathrm{N}$ ratio $(\mathrm{P}<0.05)$.

Gross nitrification was generally lower than the gross mineralization. The ratio between gross nitrification and gross mineralization tended to be higher for the deciduous soils $(0.83 \pm 0.14 ; \mathrm{n}=4 \pm \mathrm{SE})$ than for the coniferous soils $(0.50 \pm 0.14 ; n=7 \pm S E)$. Variations in the ratio occurred independently of the soil parameters listed in Tables 2 and 3.

As for gross nitrification, net nitrification fluctuated also significantly among the different sites (Fig. 4) indicating that some sites each time provided a net $\mathrm{NO}_{3}^{-}$source (e.g. Bosco negri) and others a net $\mathrm{NO}_{3}^{-}$sink (e.g. Höglwald). Net nitrification also differed significantly $(\mathrm{P}<0.05)$ between the coniferous sites $\left(-1.1 \mu \mathrm{g} \mathrm{N} \mathrm{cm}^{-3} \mathrm{~d}^{-1}\right)$ and deciduous sites $\left(1.6 \mu \mathrm{g} \mathrm{N} \mathrm{cm}^{-3} \mathrm{~d}^{-1}\right)$.

Nitrous oxide emissions were not correlated to the gross mineralization rates, neither among all sites, nor within the 

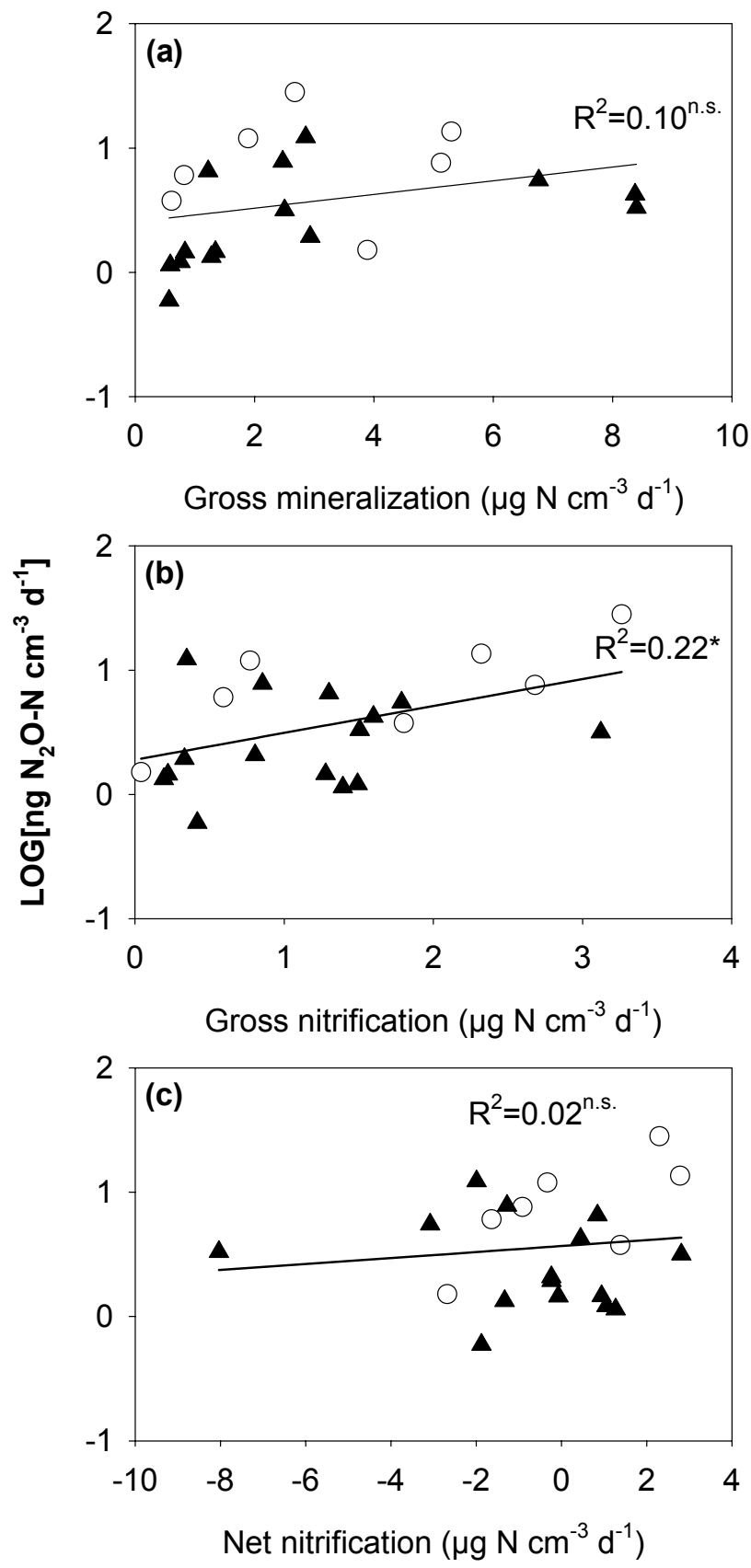

Deciduous

- Coniferous

Fig. 5. $\mathrm{X}-\mathrm{Y}$ scatter plots indicating the relationships between LOG[ $\mathrm{N}_{2} \mathrm{O}$ emission] and gross $\mathrm{N}$ mineralization activity (a), gross nitrification activity (b), and net nitrification activity (c), respectively. The positions of values for coniferous and deciduous soils are indicated by different legends. The trend lines indicate the positions of linear regressions lines when all data are included in the analysis. n.s. not significant; $* \mathrm{P}<0.05$. two forest types (Fig. 5a). However, a trend in the data $(\mathrm{P}<0.09)$ indicated a positive relationship between $\mathrm{N}_{2} \mathrm{O}$ and gross mineralization for the coniferous soils. The $\mathrm{N}_{2} \mathrm{O}$ emissions correlated significantly $(\mathrm{P}<0.03)$ with gross nitrification activities when all sites were included in the analysis (Fig. 5b). For the individual forest types, however, the $\mathrm{N}_{2} \mathrm{O}$ emissions were not correlated to gross nitrification although a positive trend $(\mathrm{P}<0.08)$ was observed for the deciduous soils. In contrast to the relationship with gross nitrification, the $\mathrm{N}_{2} \mathrm{O}$ emissions were not related to net nitrification activities, but a positive trend $(\mathrm{P}<0.08)$ could be observed for the deciduous soils (Fig. 5c).

\section{Discussion}

\subsection{Impact of forest type and C- and N-pools}

Nitrogen cycling processes in forest soils is widely believed to be regulated by litter quality parameters such as $\mathrm{C}: \mathrm{N}$ ratio, contents of $\mathrm{N}$, lignin and phenolic compounds (Venterea et al., 2004). It is also believed that deciduous tree species generally increase nutrient cycling and microbial activities compared to coniferous tree species (Menyailo et al., 2002; Smolander et al., 2005). In accordance with this general perception, incubation of intact samples from a range of European coniferous and deciduous forest soils indicated that soils under deciduous forest types emit more $\mathrm{N}_{2} \mathrm{O}$ than soils under coniferous forest types. A similar difference between these two main forest types was also observed in a field study by Butterbach-Bahl et al. (1997) who found that a German beech forest emitted approximately twice as much $\mathrm{N}_{2} \mathrm{O}$ as a spruce forest. Field measurements within the sites encountered in the current study also indicated that deciduous forests are stronger sources of $\mathrm{N}_{2} \mathrm{O}$ than coniferous forests (Butterbach-Bahl, 2005). Other soil incubation studies have also confirmed that soils under deciduous forests may emit more $\mathrm{N}_{2} \mathrm{O}$ compared with soils under coniferous forests (Menyailo and Huwe, 1999; Menyailo et al., 2002).

We also observed that the $\mathrm{N}_{2} \mathrm{O}$ production was inversely correlated to the $\mathrm{C}: \mathrm{N}$ ratio of soil carbon and nitrogen pools. This observation suggests that not only the chemical quality of the litter input, but also external factors, such as nitrogen deposition, which may have a long-term cumulated effect on the soil $\mathrm{C}: \mathrm{N}$ ratio constitute important proxy controllers for the $\mathrm{N}_{2} \mathrm{O}$ production across European forest sites. Lovett et al. (2004) found that standard measures of litter quality (e.g. N, lignin, and phenolic contents) could not explain mechanisms of control on forest $\mathrm{N}$ cycling and suggested that external factors may play an important role. In line with this, the soil characteristics encountered in this study as indices for quality of litter input (Table 2) did not differ between the two major forest types despite the different $\mathrm{N}_{2} \mathrm{O}$ emission strengths. 
The supply of inorganic $\mathrm{N}$, as expressed by gross $\mathrm{N}$ mineralization, was also similar in magnitude for the two forest types and did not explain the difference in $\mathrm{N}_{2} \mathrm{O}$ emissions. Gross mineralization in hardwood and Pine stands of Harvard Forest (Venterea et al., 2004) were similar in magnitude to those reported herein and, in agreement with our conclusion, not different between the two forest types. Not surprisingly, however, current gross mineralization increased with increasing total $\mathrm{N}$ contents among all sites and decreased with increasing $\mathrm{C}$ content. The combined effect of these two parameters thus suggests that gross mineralization would increase with a decreasing $\mathrm{C}: \mathrm{N}$ ratio of the soil organic matter, but in our analysis, this relationship was just about significant $(\mathrm{P}<0.06)$.

The extent of nitrification in relation to substrate input, as expressed by the ratio between gross nitrification and gross mineralization, is basically regulated by the competition between heterotrophic and autotrophic $\mathrm{NH}_{4}^{+}$assimilation (Venterea et al., 2004). The current data suggests that the competitive ability of nitrifying communities in deciduous soils is stronger than in the coniferous soils, which may explain why both gross and net nitrification in the deciduous sites exceeded nitrification in the coniferous sites. The magnitude of nitrification was also mediated through the soil $\mathrm{C}: \mathrm{N}$ ratio, in agreement with observations in other studies suggesting that nitrification increases with decreasing $\mathrm{C}: \mathrm{N}$ ratio below a threshold value of 22-25 (Lovett et al., 2004). The current $\mathrm{C}: \mathrm{N}$ ratios were almost all below this threshold.

In this experiment the litter layer was removed prior to sampling for methodological reasons. Presence of litter, however, may influence the $\mathrm{N}_{2} \mathrm{O}$ gas exchange and it can not be ruled out that absence of litter will lead to biased results. First of all, as demonstrated by Brüggemann et al. (2005), litter from various tree species constitute a substrate for extensive mineralization and nitrification activity, suggesting that also $\mathrm{N}_{2} \mathrm{O}$ production can take place in the litter. Moreover, different shapes of tree litters can have an influence on the gas diffusivity through the litter layer (Brumme and Borken, 1999). Litters from broad leaved trees may, in particular when they are wet, restrict oxygen diffusion into the soil to a greater extent than litters from spruce or pine needles with variable impacts on soil aeration and thus $\mathrm{N}_{2} \mathrm{O}$ emissions. Contrasting these observations, however, Vasconcelos et al. (2004) observed no changes in $\mathrm{N}_{2} \mathrm{O}$ and $\mathrm{CH}_{4}$ fluxes in a tropical forest after litter had been removed.

\subsection{Sources of $\mathrm{N}_{2} \mathrm{O}$}

Although $\mathrm{N}_{2} \mathrm{O}$ production was correlated with gross nitrification activity, the current data do imply that nitrification activity per se was not responsible for the $\mathrm{N}_{2} \mathrm{O}$ formation in most of the sites. Exceptions to this were the Achenkirch and Höglwald sites, where all the $\mathrm{N}_{2} \mathrm{O}$ was derived directly from $\mathrm{NH}_{4}^{+}$under nitrifying conditions. However, both of these sites were also capable for producing $\mathrm{N}_{2} \mathrm{O}$ entirely from $\mathrm{NO}_{3}^{-}$under similar soil moisture conditions. There is no obvious reason to explain why these two spruce sites in particular exhibited the capability to switch between $\mathrm{N}_{2} \mathrm{O}$ production entirely from nitrification or from denitrification. Common characteristics to the two sites making them distinct from the other sites were a loamy texture with relatively high contents of organic $\mathrm{C}$ and $\mathrm{N}$. This environment could sustain not only a high microbial biomass but also probably a greater microbial diversity with the capability of a rapid switch between different pathways for $\mathrm{N}_{2} \mathrm{O}$ production, i.e. nitrification, denitrification and perhaps also less well described pathways such as heterotrophic production from $\mathrm{NH}_{4}^{+}$(Wolf and Brumme, 2002). Data for the Hyytiälä pine soil also suggested a transient production of $\mathrm{N}_{2} \mathrm{O}$ from $\mathrm{NH}_{4}^{+}$in $\mathrm{Au}-$ gust (late summer) that, in combination with a reduced $\mathrm{N}_{2} \mathrm{O}$ production from $\mathrm{NO}_{3}^{-}$at the same time, do imply a shift in $\mathrm{N}_{2} \mathrm{O}$ production pathway during the season, in accordance with the observations by Wolf and Brumme (2002).

One of the most important environmental controls in the partitioning of $\mathrm{N}_{2} \mathrm{O}$ from nitrification and denitrification is soil aeration, which mainly is regulated by the soil moisture content. In the current experiment the pre-incubation soil moisture was regulated to $\mathrm{pF} 2.3$, slightly below field capacities, with the aim to promote conditions abundant following rainfall events when peak $\mathrm{N}_{2} \mathrm{O}$ emissions are anticipated to occur. Soil moisture conditions in the current range (Table 2) also favor simultaneous production of $\mathrm{N}_{2} \mathrm{O}$ from both nitrification as well as denitrification (Davidson et al., 2000). Apart for the Achenkirch and Höglwald spruce sites, however, $\mathrm{NH}_{4}^{+}$constituted a less significant source for $\mathrm{N}_{2} \mathrm{O}$ than $\mathrm{NO}_{3}^{-}$, indicating that denitrification is the most important process for $\mathrm{N}_{2} \mathrm{O}$ production across these European forests. This observation is very much in agreement with previous works by Wolf and Brumme $(2002,2003)$ who found that denitrification was responsible for $\mathrm{N}_{2} \mathrm{O}$ production in German beech forests, and Ambus (1998) finding that denitrification was the only source for $\mathrm{N}_{2} \mathrm{O}$ in Danish spruce and beech forest stands. MacDonald et al. (1997) also found evidence that denitrification was the source for $\mathrm{N}_{2} \mathrm{O}$ in Scottish Sitka spruce plantations.

It must be emphasized that the current experiment can not distinguish if the ${ }^{15} \mathrm{~N}_{2} \mathrm{O}$ generated from ${ }^{15} \mathrm{NH}_{4}^{+}$in treatment $A$ was produced as an intermediate in $\mathrm{NH}_{4}^{+}$oxidation or via nitrification denitrification reduction of nitrite (Fig. 1). In some sites, e.g. Hyytiälä, Speulderbos, and Sorø, labeled $\mathrm{N}_{2} \mathrm{O}$ was not produced in the presence of labeled $\mathrm{NH}_{4}^{+}$in spite of a significant nitrification activity, which does imply that nitrification denitrification did not contribute to the $\mathrm{N}_{2} \mathrm{O}$ production in these soils. For soils with modest $\mathrm{N}_{2} \mathrm{O}$ production from ${ }^{15} \mathrm{NH}_{4}^{+}$it can be argued that all $\mathrm{N}_{2} \mathrm{O}$ was produced by nitrification denitrification and that the isotope signal was diluted by unlabeled $\mathrm{NO}_{2}^{-}$from denitrification reduction of $\mathrm{NO}_{3}^{-}$. However, it is still debatable whether the $\mathrm{NO}_{2}^{-}$ products from nitrification $\mathrm{NH}_{4}^{+}$oxidation and denitrification 
$\mathrm{NO}_{3}^{-}$reduction, respectively, do mix in the soil due to diffusional constraints (Russow et al., 2000). In the San Rossore pine stand the lack of ${ }^{15} \mathrm{NH}_{4}^{+}$derived $\mathrm{N}_{2} \mathrm{O}$ was very likely due to the limited nitrification capacity (Fig. 4).

The key role of nitrification in the control of $\mathrm{N}_{2} \mathrm{O}$ production was thus mostly due to the supply of substrate for denitrification, except for the Höglwald and Achenkirch sites where $\mathrm{N}_{2} \mathrm{O}$ was produced by either pathway. The ratio between $\mathrm{N}_{2} \mathrm{O}$ production and gross nitrification averaged $0.67 \%$ and $0.44 \%$, respectively, for the deciduous soils and coniferous soils, which is comparable to the ratios observed in Massachusetts hardwood and pine stands (Venterea et al., 2004). Increased $N$ inputs to forest ecosystems causes in many cases symptoms of $\mathrm{N}$ saturation with increased exports of various $\mathrm{N}$ forms such as $\mathrm{NO}_{3}^{-}$leaching and gaseous losses (Venterea et al., 2004; Vervaet et al., 2004). The study by Venterea et al. (2004) suggests that these responses to increased $\mathrm{N}$ deposition may be explained by increased nitrification, although in sites with excessive $\mathrm{NO}_{3}^{-}$consumption the $\mathrm{N}$ saturation symptoms will be less apparent (Vervaet et al., 2004). Our study suggests that increased nitrification in response to accelerated $\mathrm{N}$ inputs generally may lead to increased $\mathrm{N}_{2} \mathrm{O}$ emissions from a wide range of European forest ecosystems. The positive relationship between $\mathrm{N}_{2} \mathrm{O}$ emissions and gross- and net nitrification observed among the different forest systems is generally also in support of the "hole-in-the-pipe" model proposed by Firestone and Davidson (1989). This conceptual model predicts that nitrogen oxide emissions from ecosystems is related to nitrogen cycling within the system with soil water as the most robust controller in the ratio between produced nitric oxide (NO) and $\mathrm{N}_{2} \mathrm{O}$ (Davidson et al., 2000). In the current study we attempted to maintain comparable soil moisture conditions across the sites and thereby narrow the $\mathrm{NO}: \mathrm{N}_{2} \mathrm{O}$ ratio and found the relationship between $\mathrm{N}_{2} \mathrm{O}$ emission and nitrification to be true across multiple forest ecosystems with variable physical and chemical properties.

\section{Conclusions and perspective}

Nitrous oxide emissions were measured from soil samples collected in 11 different European forests. The data indicate that $\mathrm{N}_{2} \mathrm{O}$ emission rates are greater from deciduous forest types compared with coniferous forest types. Changes in forest composition in response to land use activities and global change may thus have implications for regional budgets of greenhouse gases. The result emphasizes the need to include various forest types in field-based experiments on forest $\mathrm{N}_{2} \mathrm{O}$ fluxes. From the study it also became clear that $\mathrm{N}_{2} \mathrm{O}$ emissions were driven by the nitrification activity across all sites, although the $\mathrm{N}_{2} \mathrm{O}$ was produced per se mainly from denitrification. Increased nitrification in response to accelerated $\mathrm{N}$ inputs predicted for forest ecosystems in Europe may thus lead to increased greenhouse gas emissions from forest ecosystems.

Acknowledgements. The work was part of the Nofretete-project (EVK2-CT2001-00106) funded by the European Commission DG Research under the 5th Framework Programme.

Edited by: F. X. Meixner

\section{References}

Ambus, P.: Nitrous oxide production by denitrification and nitrification in temperate forest, grassland and agricultural soils., Eur. J. Soil Sci., 49, 495-502, 1998.

Ambus, P. and Christensen, S.: Spatial and seasonal nitrous oxide and methane fluxes in Danish forest-, grassland-, and agroecosystems, J. Environ. Qual., 24, 993-1001, 1995.

Bowden, R. D., Steudler, P. A., and Melillo, J. M.: Annual nitrous oxide fluxes from temperate forest in the Northeastern United States, J. Geophys. Res., 95, 13 997-14 005, 1990.

Brumme, R. and Borken, W.: Site variation in methane oxidation as affected by atmospheric deposition and type of temperate forest ecosystem, Global Biogeochem. Cycles, 13, 493-501, 1999.

Brüggemann, N., Rosenkranz, P., Papen, H., Pilegaard, K., and Butterbach-Bahl, K.: Pure stands of temperate forest tree species modify soil respiration and $\mathrm{N}$ turnover, Biogeosciences Discuss., 2, 303-331, 2005,

\section{SRef-ID: 1810-6285/bgd/2005-2-303.}

Butterbach-Bahl, K.: Final report. Nitrogen oxides emissions from European forest ecosystems (NOFRETETE), EVK2-CT-200100106 to the European Commission DG Research, 2005.

Butterbach-Bahl K., Gasche R., Breuer L., and Papen, H.: Fluxes of $\mathrm{NO}$ and $\mathrm{N}_{2} \mathrm{O}$ from temperate forest soils: impact of forest type, $\mathrm{N}$ deposition and of liming in the $\mathrm{NO}$ and $\mathrm{N}_{2} \mathrm{O}$ emissions, Nutr. Cycl. Agroecosys., 48, 79-90, 1997.

Butterbach-Bahl, K., Kesik, M., Miehle, P., Papen, H., and Li, C.: Quantifying the regional source strength of N-trace gases across agricultural and forest ecosystems with process based models, Plant Soil, 260, 311-329, 2004.

Conrad, R.: Microbiological and biochemical background of production and consumption of $\mathrm{NO}$ and $\mathrm{N}_{2} \mathrm{O}$ in soil, in: Trace Gas Exchange in Forest Ecosystems, edited by: Gasche, R., Papen, H., and Rennenberg, H., Kluwer Academic Publishers, Dordrecht, Netherlands, pp. 3-33, 2002.

Dalsgaard, T., Canfield, D. E., Petersen, J., Thamdrup, B., and Acuñja-González, J.: $\mathrm{N}_{2}$ production by the anammox reaction in the anoxic water column of Golfo Dulce, Costa Rica, Nature, 422, 606-608, 2003.

Davidson, E. A., Keller, M., Erickson, H. E., Verchot, L. V., and Veldkamp, E.: Testing a conceptual model of soil emissions of nitrous and nitric oxides, BioScience, 50, 667-680, 2000.

Firestone, M. K. and Davidson, E. A.: Microbiological basis of $\mathrm{NO}$ and $\mathrm{N}_{2} \mathrm{O}$ production and consumption in soil, in: Exchange of Trace Gases between Terrestrial Ecosystems and the Atmosphere, edited by: Andreae, M. O. and Schimel, D. S., John Wiley and Sons Ltd, 7-21, 1989.

IPCC: Climate Change 2001: The scientific basis. Contribution of working group I to the third assessment report of the Intergovernmental Panel on Climate Change, edited by: Houghton, J. 
T., Ding, Y., Griggs, D. J., Noguer, M., van der Linden, P. J., Dai, X., Maskell, K., and Johnson, C. A., Cambridge University Press, Cambridge, UK and New York, NY, USA, 2001.

Kirkham, D. and Bartholomew, W. V.: Equations for following nutrient transformations in soil, utilizing tracer data., Soil Sci. Soc. Am. Proc., 18, 33-34, 1954.

Kroeze, C., Aerts, R., van Breemen, N., van Dam, D., van der Hoek, K., Hofschreuder, P., Hoosbeek, M., de Klein, J., Kros, H., van Oene, H., Oenema, O., Tietema, A., van der Veeren, R., and de Vries, W.: Uncertainties in the fate of nitrogen I: An overview of sources of uncertainty illustrated with a Dutch case study., Nutr. Cycl. Agroecosys., 66, 43-69, 2003.

Lovett G. M., Weathers K. C., Arthur M. A., and Schultz J. C.: Nitrogen cycling in a northern hardwood forest. Do species matter?, Biogeochem., 67, 289-308, 2004.

MacDonald, J. A., Skiba, U., Sheppard, L. J., Ball, B., Roberts, J. D., Smith, K. A., and Fowler, D.: The effect of nitrogen deposition and seasonal variability on methane oxidation and nitrous oxide emission rates in an upland spruce plantation and moorland, Atmos. Environ., 31, 3693-3706, 1997.

Menyailo, O. V., Hungate, B. A., and Zech, W.: The effect of single tree species in soil microbial activities related to $\mathrm{C}$ and $\mathrm{N}$ cycling in the Siberian artificial afforestation experiment, Plant Soil, 242, 183-196, 2002.

Menyailo, O. and Huwe, B.: Activity of denitrification and dynamics of $\mathrm{N}_{2} \mathrm{O}$ release in soils under six tree species and grassland in central Siberia, J. Plant Nutr. Soil Sc., 162, 533-538, 1999.

Papen, H. and Butterbach-Bahl, K.: A 3-year continuous record of nitrogen trace gas fluxes from untreated and limed soil of a Nsaturated spruce and beech forest ecosystem in Germany $1 . \mathrm{N}_{2} \mathrm{O}$ emissions, J. Geophys. Res.-Atmos., 104, 18 487-18 503, 1999.

Russow, R., Sich, I., and Neue, H.-U.: The formation of the trace gases $\mathrm{NO}$ and $\mathrm{N}_{2} \mathrm{O}$ in soils by the coupled processes of nitrification and denitrification: Results of kinetic ${ }^{15} \mathrm{~N}$ tracer investigations, Chemosphere - Global Change Sci., 2, 359-366, 2000.

Schindlbacher, A. and Zechmeister-Boltenstern, S.: Effects of soil moisture and temperature on $\mathrm{NO}, \mathrm{NO}_{2}$, and $\mathrm{N}_{2} \mathrm{O}$ emissions from European forest soils, J. Geophys. Res., 109, D17302, doi:10.1029/2004JD004590, 2004.

Schmidt, J., Seiler, W., and Conrad, R.: Emission of nitrous oxide from temperate forest soils into the atmosphere, J. Atmos. Chem., 6, 95-115, 1998.
Skiba, U., Sheppard, L. J., Pitcairn, C. E. R., van Dijk, S., and Rossall, M. J.: The effect of $\mathrm{N}$ deposition on nitrous oxide and nitric oxide emissions from temperate forest soils, Water Air Soil Poll., 116, 89-98, 1999.

Smolander A., Loponen J., Suominen K., and Kitunen V.: Organic matter characteristics and $\mathrm{C}$ and $\mathrm{N}$ transformations in the humus layer under two tree species, Betula pendula and Picea abies, Soil Biol. Biochem., 37, 1309-1318, 2005.

Struwe, S. and Kjøller, A.: Potential for $\mathrm{N}_{2} \mathrm{O}$ production from beech (Fagus sylvaticus) forest soils with varying $\mathrm{pH}$., Soil Biol. Biochem., 26, 1003-1009, 1994.

Sørensen, P. and Jensen, E. S.: Sequential diffusion of ammonium and nitrate from soil extracts to a polytetrafluoroethylene trap for ${ }^{15} \mathrm{~N}$ determination, Anal. Chim. Acta, 252, 201-203, 1991.

Vasconcelos, S. S., Zarin, D. J., Capanu, M., Littell, R., Davidson, E. A., Ishida, F. Y., Santos, E. B., Araujo, M. M., Aragao, D. V., Rangel-Vascolencos, L. G. T., Oliveira, F. D., McDowell, W. H., and de Carvalho, C. J. R.: Moisture and substrate availability constrain soil trace gas fluxes in an eastern Amazonian regrowth forest, Global Biogeochem. Cycles, GB2009, 18, 2004.

Venterea, R. T., Groffman, P. M, Verchot, L. V., Magill, A. H., and Aber, J. D.: Gross nitrogen process rates in temperate forest soils exhibiting symptoms of nitrogen saturation, Forest Ecol. Manag., 196, 129-142, 2004.

Vervaet, H., Boeckx, P., Boko, A. M. C., Van Cleemput, O., and Hofman, G.: The role of gross and net $\mathrm{N}$ transformation processes and $\mathrm{NH}_{4}^{+}$and $\mathrm{NO}_{3}^{-}$immobilization in controlling the mineral $\mathrm{N}$ pool of a temperate mixed deciduous forest soil, Plant Soil, 264, 349-357, 2004.

Wolf, I. and Brumme, R.: Contribution of nitrification and denitrification sources for seasonal $\mathrm{N}_{2} \mathrm{O}$ emissions in an acid German forest soil, Soil Biol. Biochem., 34, 741-744, 2002.

Wolf, I. and Brumme, R.: Dinitrogen and nitrous oxide formation in beech forest floor and mineral soils, Soil Sci. Soc. Am. J., 67, 1862-1868, 2003.

Wrage, N., Velthof, G. L., van Beusichem, M. L., and Oenema, O.: Role of nitrifier denitrification in the production of nitrous oxide, Soil Biol. Biochem., 33, 1723-1732, 2001. 